
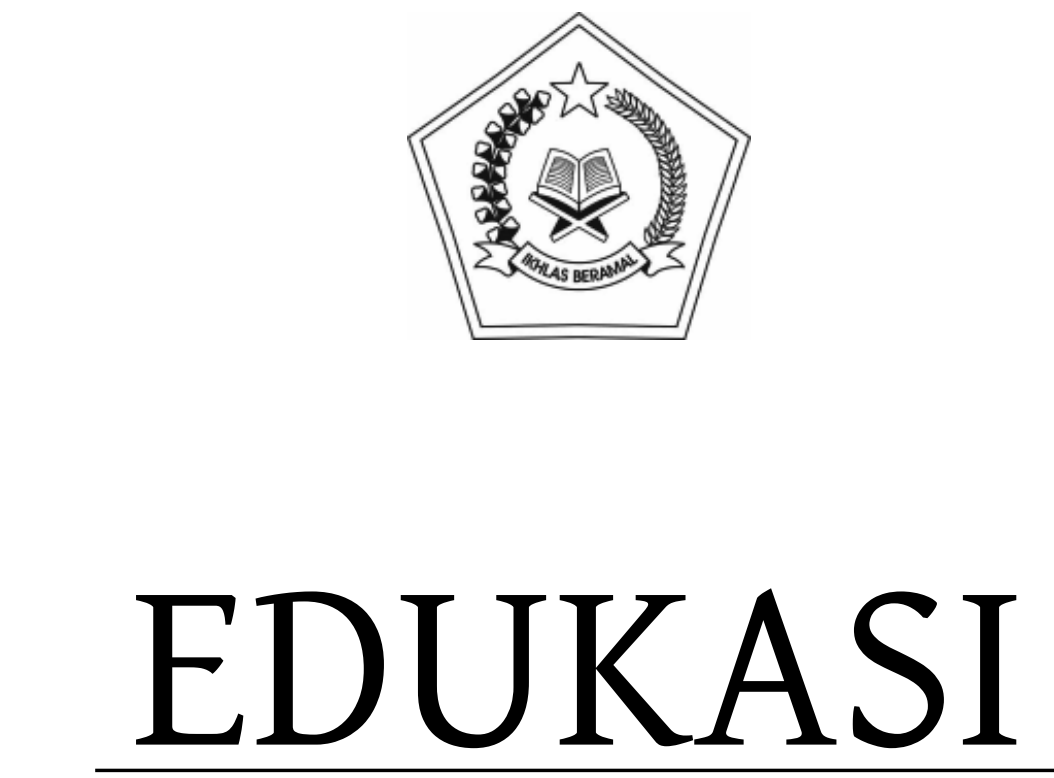

JURNAL PENELITIAN PENDIDIKAN AGAMA DAN KEAGAMAAN

VOLUME 13, NOMOR 3, DESEMBER 2015 


\title{
MODEL PEMBENTUKAN KARAKTER RELIGIUS SANTRI TAHFIDZ AL-QUR'AN DI PONDOK PESANTREN MATHALI'UL HUDA PUSAT KAJEN PATI
}

\author{
RELIGIOUS CHARACTER FORMATION MODEL \\ ON STUDENT OF TAHFIDZ AL-QUR'AN (QURAN \\ MEMORIZER) AT MATHALI'UL HUDA ISLAMIC \\ BOARDING SCHOOL, KAJEN PATI
}

\author{
Faiqoh \\ Puslitbang Pendidikan Agama dan Keagamaan Badan Litbang dan Diklat Kementerian Agama RI \\ Jl. MH Thamrin No. 6 Jakarta Pusat \\ Email: faiqoh_mhum@yahoo.com
}

Sahal Mahfudh

Santri PP Mathali'ul Huda Pusat Kajen Pati

Jl. Polgarut Selatan Kajen - Margoyoso - Pati Jawa Tengah

Email: sahla.mahfudz@gmail.com

Naskah diterima 25 Nopember 2015, direvisi 2 Desember 2015, disetujui 15 Desember 2015

\begin{abstract}
This writing is intended to review a formation model on religious student character for tahfidz at Mathali'ul Huda Boarding School, Kajen. This study is important since the implementation of character education at educational institution existing in Indonesia requires a good model, and boarding school is assessed able to become a good model in implementing the character education especially for a religious character. There are numerous schools unable to become a place to transfer knowledge and to form character of its student. This research includes type of onsite research using a verificative qualitative approach where the research is directly conducted at Mathali'ul Huda Boarding School by presenting theory to become a frame to analyze the research finding outcome. Data collection method used is carried out through interview, observation and documentation. Meanwhile, this research finds that there are five stages on the formation of the religious student of tahfidz at Mathali'ul Huda Boarding School, namely: 1. stage on religious character value knowledge; 2. stage on religious character value awareness; 3. stage on religious character implementation; 4. religious character habituation; fifth, stage on long life religious character preservation.
\end{abstract}

Keyword : Religious character formation model, student of tahfidz al-Qur'an.
Abstrak

Tulisan ini mengkaji tentang model pembentukan karakter religius santri tahfidz di Pondok Pesantren Mathali'ul Huda Pusat Kajen. Kajian ini penting, karena implementasi pendidikan karakter di lembaga pendidikan yang ada di Indonesia membutuhkan good model, dan pesantren dinilai mampu menjadi model yang baik dalam mengimplementasikan pendidikan karakter khususnya karakter religius. Selama ini banyak sekolah belum mampu menjadi tempat untuk memindahkan pengetahuan sekaligus membentuk karakter peserta didiknya. Penelitian ini termasuk dalam jenis penelitian lapangan yang menggunakan pendekatan kualitatif verifikatif, dimana peneliti terjun secara langsung di Pondok Pesantren Mathali'ul Huda dengan membawa teori yang dijadikan frame untuk menganalisa hasil temuan penelitian. Tekhnik pengambilan data yang digunakan adalah wawancara, observasi dan dokumentasi. Adapun hasil penelitian ini menemukan bahwa ada lima tahapan pembentukan karakter religius santri tahfidz di Pondok Pesantren Mathali'ul Huda Pusat, yaitu: 1. tahapan pengetahuan nilai karakter religius; 2. tahapan kesadaran nilai karakter religius; 3. tahapan pengamalan karakter religius; 4. tahapan pembiasaan karakter religius; kelima, tahapan penjagaan karakter religius sepanjang hayat.

Kata Kunci: model pembentukan karakter religius, santri tahfidz al-Qur'an. 


\section{PENDAHULUAN}

Isu mengenai pendidikan karakter merebak, setelah diketahui berdasarkan berbagai peristiwa yang terjadi, bahwasanya moral anak bangsa telah merosot begitu tajamnya. Hal ini disebabkan antara lain karena pada kenyataannya, banyak sekolah di Indonesia hanya menjadi tempat untuk memindahkan pengetahuan (transfer of knowledge) baik pengetahuan secara umum maupun pengetahuan tentang etika, dan belum sampai pada taraf pembentukan moral dan etika (character building). Banyak orang tua dan guru-guru belum mampu menjadi good model bagi anak-anaknya. Banyak lingkungan sosial rusak karena tidak memiliki sistem kontrol yang baik untuk mengawasi anak-anak sehingga mereka bisa bebas melakukan apa saja. ${ }^{1}$ Sehingga hal ini menjadi sebuah permasalahan besar bagi bangsa Indonesia, terutama bagi lembaga pendidikan di Indonesia sebagai tempat mendidik anak-anak bangsa.

Idealnya, lembaga pendidikan yang ada di Indonesia disamping menjadi tempat mentrasfer ilmu, juga mampu menjadi tempat membentuk karakter dan moral peserta didiknya. Karakter merupakan sebagai sifat-sifat kejiwaan, akhlak atau budi pekerti yang membedakan seseorang dari yang lain. ${ }^{2}$ Salah satu nilai karakter yang erat kaitannya dengan moral adalah karakter religius, yaitu sikap dan perilaku yang patuh dalam melaksanakan ajaran agama yang dianutnya, toleran terhadap pelaksanaan ibadah agama lain, dan hidup rukun dengan pemeluk agama lain. ${ }^{3}$ Karakter manusia termasuk juga karakter religius bukanlah

${ }^{1}$ Muhlas Samani \& Haryanto. 2013. Pendidikan Karakter: Konsep dan Model. Bandung: Remaja Rosda Karya, h. 3-5

${ }^{2}$ Departemen Pendidikan Nasional, Kamus Besar Bahasa Indonesia,.. h. 623.

${ }^{3}$ Op. Cit., h. 22. sesuatu yang tetap, karena ia bisa dibentuk melalui berbagai cara. Salah satunya adalah melalui pendidikan. ${ }^{4}$ Sekolah-sekolah seharusnya mampu memberikan solusi atas dekadensi moral anak bangsa dengan mengimplementasikan pendidikan berbasis karakter, sehingga peserta didiknya disamping memiliki kemampuan profesional pada ilmu yang ditekuni, sekaligus juga memiliki etika, moral dan karakter yang membedakan dirinya dengan orang-orang yang tidak mengenyam pendidikan.

Secara tekhnis, pendidikan berbasis karakter dapat diimplementasikan melalui beberapa cara, yaitu dengan mengajarkan mata pelajaran khusus yang berisi tentang pelajaran moral, mengelompokkan mata pelajaran yang memuat nilai karakter, membuat peraturan yang berbasis nilai-nilai karakter, atau melalui proses pendidikan sepanjang hayat. ${ }^{5}$ Adapun tahapan-tahapan yang dapat ditempuh dalam mengimplementasikan pendidikan karakter adalah sebagai berikut: pertama, memberikan pengetahuan tentang kebaikan (moral knowing); kedua, menumbuhkan kesadaran tentang kebaikan (moral feeling); dan ketiga, mendorong peserta didik untuk melakukan kebaikan (moral behavior). ${ }^{6}$

Di tengah persoalan dekadensi moral yang melanda anak-anak bangsa, muncul sebuah gerakan untuk kembali kepada pondok pesantren, yakni dengan menjadikan pondok pesantren sebagai percontohan dalam pelaksanaan pendidikan berbasis

${ }^{4}$ Doni A Koesoema. 2011. Pendidikan Karakter: Strategi Mendidik Anak di Zaman Global. Jakarta: Grasindo, , h. 6.

${ }^{5}$ Doni Koesoema. 2012. Pendidikan Karakter Utuh dan Menyeluruh. Yogyakarta: Kanisius, h. 7.

${ }^{6}$ Thomas Lickona. 2013. Educating for Character. Bandung: Nusa Media, h. 71-72. 
karakter. ${ }^{7}$ Pesantren dipandang mampu menjadi good model dalam pelaksanaan pendidikan karakter di Indonesia, karena pesantren merupakan lembaga pendidikan tradisional keagamaan yang mandiri ${ }^{8}$ dan sangat mengedepankan etika (akhlaq) atau moral, yang mengajarkan ilmu-ilmu agama kepada para peserta didiknya (baca: santri), dan senantiasa berusaha untuk membentuk kepribadian mulia (akhlaqul karimah) para santri yang sesuai dengan nilai-nilai agama, bangsa dan negara. Selain itu, pesantren juga mengajarkan para santri ketika sudah lulus untuk selalu berjuang mengabdi kepada masyarakat sebagai wujud pengabdian kepada agama dan negara.

Mathali'ul Huda sebagai salah satu pesantren tertua ${ }^{9}$ di Kajen ${ }^{10}$ memiliki ciri dan karakter khas yang membedakannya

${ }^{7}$ Baru-baru ini sedang hangat diperbincangkan gerakan \#AyoMondok yang diluncurkan secara resmi oleh Pengurus Besar Nahdlatul Ulama (PBNU) atas prakarsa Rabithah Ma'ahid Islami (RMI) sebagai solusi dan jawaban atas permasalahan pendidikan moral anak bangsa. Gerakan nasional yang diluncurkan pada tanggal 1 Juni 2015 ini merupakan seruan sekaligus ajakan kepada masyarakat untuk kembali ke pesantren, karena pesantren dinilai mampu menyelesaikan krisis moral anak bangsa yang sedang merosot begitu tajamnya. Lihat: Gerakan Nasional Ayo Mondok Dilincurkan, NU Online, 01/06/2015.

8 Sejak pertama kali muncul (tidak dapat dipastikan kapan), pesantren merupakan symbol perlawanan penduduk pribumi terhadap penjajahan Belanda.Pesantren sama sekalitidakmaubekerjasama dengan pemerintah colonial Belanda. Karena ia punya prinsip dan memegang teguh prinsip-prinsipnya tersebut. Dengan berkejasama dengan pemerintah Belanda, sama juga mendukung penjajahan atas Indonesia. Lihat: Zamakhsyari Dhofier, Tradisi Pesantren..., hlm. 60-61. Dan sampai sekarang pun, pesantren masih mandiri dan mengambil bentuknya sendiri baik pemerintah peduli ataupun tak peduli.

${ }^{9}$ Didirikan oleh $\mathrm{KH}$ Abdussalam sekitar tahun 1912, kemudian diteruskan oleh KH Abdullah Salam, dan sekarang diasuh oleh KH Ahmad Nafi' Abdillah.

10 Sebuah desa yang terletak di Kecamatan Margoyoso Kabupaten Pati Propinsi Jawa Tengah. dengan pesantren lain. Pesantren Mathali'ul Huda (selanjutnya PMH Pusat) disamping mendidik para santri agar mahir dalam membaca kitab kuning, juga mempersiapkan para santrinya agar menjadi seorang yang hafidz $z^{11}$ al-Qur'an yang memiliki karakter religius. Dari tahun ke tahun, sudah begitu banyak alumni santri tahfidz PMH Pusat yang menjaga karakter religius sehingga mampu memberikan kontribusi positif bagi masyarakat. ${ }^{12}$ Dengan demikian, PMH Pusat Kajen bisa dijadikan good model dalam pelaksanaan pendidikan karakter khususnya pembentukan karakter religius di lembagalembaga pendidikan di Indonesia.

Berdasarkan deskripsi tersebut, maka tujuan dari penulisan ini adalah : pertama, bagaimana peranan elemen pesantren yang ada di PMH Pusat dalam membentuk karakter religius santri tahfidz; kedua, bagaimana model pembentukan karakter religius santri tahfidz di Pesantren Mathaliul Huda Pusat Kajen Pati Jawa Tengah.

\section{Kerangka Konseptual}

\section{Pengertian Karakter Religius}

Dalam Kamus Besar Bahasa Indonesia, karakter dimaknai sebagai sifat-sifat

${ }^{11}$ Hafidz berasal dari kata hafidza-yahfdzu yang secara etimologi berarti: menjaga, menghafal. (Lihat: Ahmad Warson Munawwir, Kamus al-Munawwir, Yogyakarta: Pustaka Progressif, 1997, 279). Secara istilah yang berkembang di kalangan pesantren Indonesia, hafidz dimaknai sebagai seorang yang hafal al-Qur'an dan senantiasa menjaga hafalannya dengan membacanya dan mengamalkan ayat-ayatnya.

12 Diantara santri tahfidz al-Qur'an alumnus Pondok Pesantren Mathali'ul Huda adalah: KH Ulin Nuha Arwani \& KH Ulil Albab Arwani (Pengasuh PonPes Tahfidz Yanbu'ul Quran Kudus), KH In'amutaqqi (Pengasuh PonPes Tahfidz BUQ Betengan Demak), KH Mahfudh Sulaiman (Pengasuh PonPes Tahfidz Roudlotul Mubtadiin Jepara) KH Ubaidillah (Pengasuh PonPes Tahfidz Darul Quran Islamy Tegal) dst. (Lihat: Pondok Pesantren Mathali'ul Huda, Buku Induk Santri dari tahun 1963-sekarang) 
kejiwaan, akhlak atau budi pekerti yang membedakan seseorang dari yang lain..$^{13}$ Dari pengertian karakter yang dijelaskan dalam KBBI ini, dapat dipahami bahwa karakter memiliki dua dimensi, yaitu: 1. Dimensi dalam (aspek psikologis) meliputi sifat-sifat kejiwaan manusia yang ada dalam diri manusia. 2. Dimensi luar (aspek psikomotorik) meliputi sikap, akhlak dan budi pekerti yang dilakukan seseorang dalam suatu keadaan. Dimensi luar ini dapat diindera karena ia merupakan sikap, perbuatan dan tindakan. Hal ini senada dengan kajian pendidikan karakter dalam Islam yang membedakan dimensi dalam yang dibahasakan dengan khuluq dan dimensi luar yang dibahasakan dengan khalq yang keduanya merupakan satu kesatuan dari akhlaq yang berarti etika, budi pekerti atau karakter. ${ }^{14}$

Pendidikan karakter yang tengah dicanangkan oleh pemerintah didasarkan pada delapan belas nilai karakter yang bersumber dari nilai-nilai agama, nilai-nilai pancasila dan nilai-nilai budaya. Kedelapan belas nilai karakter tersebut adalah: (1) Religius (2) Jujur (3) Toleransi (4) Disiplin (5) Kerja Keras (6) Kreatif (7) Mandiri (8) Demokratis (9) Rasa Ingin Tahu (10) Semangat Kebangsaan (11) Cinta Tanah Air (12) Menghargai Prestasi (13) Bersahabat (14) Cinta Damai (15) Gemar Membaca (16) Peduli Lingkungan (17) Peduli Sosial (18) Tanggung Jawab. ${ }^{15}$

Salah satu nilai karakter yang menjadi obyek kajian dalam penelitian ini adalah nilai karakter religius. Karakter religius

\footnotetext{
${ }^{13}$ Departemen Pendidikan Nasional. 2008. Kamus Besar Bahasa Indonesia. Jakarta: Gramedia Pustaka Utama, h. 623.

${ }^{14}$ Ahmad Warson Munawwir. 1997. Kamus alMunawwir Yogyakarta: Pustaka Progresif, , Cet ke-14, h 364 .

${ }^{15}$ Muhlas Samani \& Haryanto. 2013. Pendidikan Karakter: Konsep dan Model. Bandung: Remaja Rosda Karya, h 52.
}

dimaknai sebagai sikap dan perilaku yang patuh dalam melaksanakan ajaran agama yang dianutnya, toleran terhadap pelaksanaan ibadah agama lain, dan hidup rukun dengan pemeluk agama lain. ${ }^{16}$ Bisa difahami bahwa karakter religius dalam pengertian tersebut merupakan sinergitas antara ibadah yang berhubungan dengan Tuhan (hablun minallah) dan ibadah yang berhubungan dengan manusia (hablun minan naas). ${ }^{17}$

Pengertian tentang karakter religius yang telah disebutkan di atas masih bersifat umum, sehingga membutuhkan penjelasan agar penelitian ini terfokus pada satu obyek kajian. Adapun nilai karakter religius jika dihubungkan dengan obyek penelitian yakni pembentukan karakter religus santri tahfidz al-quran, maka dapat dipahami bahwa nilai karakter religius dalam menghafalkan al-quran (tahfidz al-quran) adalah sebagai berikut: (1) Mengaji al-quran dengan sungguh-sungguh; (2) Membaca al-quran kapan pun dan dimana pun; (3) Mengamalkan isi dan kandungan al-quran; (4) Menjaga hafalan yang telah dihafalkan; (5) Mengajarkan al-quran kepada siapa saja yang membutuhkan dengan ikhlas tanpa mengharapkan imbalan.

\section{Pembentukan Karakter Religius}

Penulis sepakat dengan pendapat bahwa karakter manusia dapat terbentuk melalui faktor-faktor bawaan dan juga faktor-

\footnotetext{
${ }^{16}$ Kementrian Pendidikan Nasional, Pengembangan Pendidikan Budaya dan Karakter Bangsa, h 10-11.

17 Zayadi. 2001. Desain Pendidikan Karakter, Jakarta: Kencana Pramedia Group, h. 73.
} 
faktor lingkungan. ${ }^{18}$ Berdasarkan teori ini, maka karakter religius pun dapat dibentuk. Pembentukan karakter seseorang termasuk juga karakter religius dapat dilakukan melalui tiga tahap, yaitu:

Pertama, tahapan pengetahuan tentang kebaikan (moral knowing). Pengetahuan tentang kebaikan atau moral dapat dicapai melalui langkah-langkah berikut: Kesadaran moral (2) Mengetahui tentang nilai-nilai moral (3) Pengambilan perspektif (4) Penalaran moral (5) Membuat keputusan (6) Memahami diri sendiri. ${ }^{19}$

Kedua, tahapan sikap dalam kebaikan (moral feeling). Sikap dalam kebaikan atau moral dapat dicapai melalui langkah-langkah berikut: (1) Merasakan moral dalam hati nurani (2) Penghargaan diri (3) Berempati (4) Mencintai kebaikan (5) Mengontrol diri (6) Kerendahan hati. ${ }^{20}$

Ketiga, tahapan tindakan terhadap kebaikan (moral behaviour). Tindakan terhadap kebaikan dapat dicapai melalui langkah-langkah berikut: (1) Kompetensi moral (2) Kehendak untuk melakukan kebaikan (3) Kebiasaan melakukan kebaikan. $^{21}$

\section{METODOLOGI PENELITIAN}

Penelitian ini termasuk dalam jenis penelitian kualitatif yang bersifat lapangan

18 Bimo Walgito, Pengantar Psikologi Umum, (Yogyakarta: Penerbit Andi, Tahun 2004), hlm. 45. Sebagai penguat, perhatikan hadits berikut: "Tiada seorang anak pun yang dilahirkan kecuali dilahirkan berdasarkan fitrahnya. Maka kedua orang tuanya la hyang membuatnya menjadi Yahudi atau membuatnya menjadi Nashrani atau membuatnya menjadi Majusi... al-Hadits." (HR al-Bukhari). Lihat: Abu Abdillah al-Bukhari, Shahih Bukhari, (Damaskus: Daar Thauq an-Najah, tt, jilid 8), h. 122.

${ }^{19}$ Thomas Lickona, 2013. Educating for Character, Bandung: Nusa Media, h. 75-79.

${ }^{20}$ Ibid, h. 79-85.

${ }^{21}$ Ibid, h. 86-87. (field research), dimana peneliti terjun secara langsung di tempat yang diteliti, yaitu Pondok Mathaliul Huda (PMH) Pusat Kajen. Sedangkan pendekatan yang dipakai dalam penelitian ini adalah kualitatif verifikatif dimana teori ditempatkan sebagai frame, bukan sebagai pisau analisis. Teknik pengambilan data dilakukan melalui wawancara, observasi dan dokumnetasi. Wawancara dilakukan dengan pimpinan pondok, para ustad, alumni dan santri PMH bertujuan mengetahui tentang peranan elemen pesantren dan bagaimana model pembentukan karakter religius santri tahfidz di Pesantren Mathaliul Huda Pusat Kajen. Teknik observasi atau pengamatan yaitu mengamati terhadap kehidupan sehari-hari para santri tahfidz al-Quran kaitannya dengan karakter religius. Sementara dokumentasi dilakukan untuk menelusuri dokumendokumen penting untuk memperkuat sebagai bahan bukti untuk memperkuat penelitian tentang model pembentukan karakter religius santri tahfidz al-quran di Pondok Pesantren Mathali'ul Huda Pusat Kajen. Sementara Analisa data menggunakan tekhnik Miles \& Hubermen terdiri dari mereduksi data, penyajian data, korelasi data, konseptualisasi data, penyimpulan data dan diberikan saran.

\section{HASIL DAN PEMBAHASAN}

\section{Profil Pondok Pesantren Mathali'ul Huda Pusat Kajen}

PMH Pusat merupakan salah satu diantara puluhan pondok pesantren yang ada di Kajen. ${ }^{22}$ PMH Pusat terletak di jalan polgarut selatan Desa Kajen Kecamatan Margoyoso Kabupaten Pati Propinsi Jawa

${ }^{22}$ Jumlah pondok pesantren di Kajen dan sekitarnya ada sekitar 50-an pondok pesantren. 
Tengah. ${ }^{23}$ PMH Pusat didirikan pada tahun 1912 --- bersamaan dengan berdirinya Perguruan Islam Mathali'ul Falah (Matholek) --- oleh KH Abdussalam bin Abdullah bin Isma'il seorang ulama ahlul quran akrab dengan panggilan Mbah Salam ${ }^{24}$, yang merupakan ayah dari KH Mahfudh Salam, KH Abdullah Zein Salam, KH Ali Mukhtar Salam, yang juga merupakan kakek dari $\mathrm{KH}$ MA Sahal Mahfudh. Setelah KH Abdussalam wafat, PMH Pusat diasuh oleh $\mathrm{KH}$ Abdullah Salam. Kemudian sepeninggal $\mathrm{KH}$ Abdullah Salam, PMH Pusat sampai sekarang diasuh oleh KH Ahmad Nafi' Abdillah.

PMH Pusat merupakan pondok pesantren salafiyah yang pada umumnya hanya mengajarkan ilmu agama Islam saja. Hal ini bisa terlihat dari kenyataan bahwa yang ditekankan di PMH Pusat adalah ilmuilmu yang berhubungan dengan keagamaan saja seperti ilmu fiqih, ilmu tauhid, ilmu nahwu, ilmu tajwid, ilmu tashawwuf, dan lain sebagainya. Sedangkan untuk ilmuilmu selain agama tidak diajarkan karena sudah diajarkan di sekolah-sekolah maupun madrasah-madrasah sekitar pesantren.

Adapun santri yang tinggal (muqim) di PMH Pusat dapat dikelompokkan menjadi tiga bagian, yaitu: (1) Santri tahfidz, yaitu santri yang menghafalkan al-Qur'an;

${ }^{23}$ Karena terletak di Polgarut Selatan, maka Mathali'ul Huda lebih dikenal dengan nama PMH Pusat yang merupakan singkatan dari Pondok Pesantren Mathali'ul Huda Polgarut Selatan. Ada juga pesantren yang dikenal dengan PMH Putra yang merupakan singkatan dari Pondok Pesantren Maslakul Huda polgarut utara, pesantren yang pernah diasuh oleh beliau KH MA Sahal Mahfudh (alm) dan sekarang diasuh oleh putranya yaitu $\mathrm{KH}$ Abdul Ghaffar Rozien. Selain itu ada juga PMH Timur yang merupakan singkatan dari Pondok Pesantren Mathali'ul Huda polgarut timur, pesantren yang pernah diasuh oleh $\mathrm{KH}$ Shiddiq (alm) dan sekarang diasuh oleh Kyai Ubaida Hamid.

24 Pondok Pesantren Mathali'ul Huda Pusat, Anggaran Dasar \& Anggaran Rumah Tangga, (Pati: PMH Pusat).
(2) Santri sekolah, yaitu santri yang mengenyam pendidikan di sekolah formal; (3) Santri ndalem, yaitu santri yang menjadi abdi ndalem kyai.

\section{Sistem Pendidikan Pesantren}

Pelaksanaan pendidikan di PMH Pusat secara umum masih menggunakan sistem non-klasikal atau sistem tradisional. Dalam pengajian kitab misalnya, metode yang digunakan adalah metode bandongan ${ }^{25}$ dan metode sorogan ${ }^{26}$. Sedangkan dalam pengajian al-Qur'an, metode yang digunakan adalah metode musyafahah. Musyafahah merupakan kata Bahasa Arab berbentuk adverb (mashdar) dari kata kerja (fi'il madhi) syaafaha-yusyaafihu, yang berarti: berbicara dari mulut ke mulut. ${ }^{27}$ Secara istilah, musyafahah diartikan sebagai suatu metode dalam membaca al-Qur'an dengan prosedur sebagai berikut: pertama, kyai atau guru membaca al-Qur'an, sementara santri mendengarkan dan menyimak dengan seksama; kedua, santri membaca alquran di hadapan kyai, sementara kyai menyimak dengan seksama dan mengoreksi apabila ada kesalahan..$^{28}$

Di PMH Pusat, santri tahfidz dibebaskan memilih kepada kyai siapa ia mengaji, selama kyai tempat dimana santri tersebut

${ }^{25}$ Metode bandongan adalah sebuah pengajian kitab kuning dimana kyai sebagai pendidik membaca kitab kuning sementara santri mendengarkan dan memaknai di kitab kuningnya masing-masing.

${ }^{26}$ Metode sorogan adalah sebuah pengajian kitab dimana santri menyetorkan bacaan kitab kuning beserta maknanya kepada kyai dengan membaca kitab kuning yang masih gundul tanpa makna, sementara kyai menyimak dan mengoreksi apabila ada kesalahan.

${ }^{27}$ Ahmad Warson Munawwir, Kamus alMunawwir..., h 730

28 Muhammad Shodiq Qomhawi, al-Burhan $f i$ Tajwid al-Qur'an, (Kaero: Maktabah al-Azhar, tt) h 5 
mengaji memiliki sanad ${ }^{29}$ yang ittshal $^{30}$ kepada Baginda Rasul Muhammad SAW, meskipun kyai tersebut pengasuh pesantren lain atau bahkan tidak memiliki pesantren. Sehingga dalam hal ini, guru mengaji santri tahfidz al-Qur'an di PMH Pusat berbeda-beda.

Sebelum menyetorkan hafalan alQur'an dengan ber-musyafahah secara langsung kepada kyai, santri tahfidz harus menjalani program persiapan (i'dad) dimana santri tahfidz harus mentashihkan bacaan al-Qur'an kepada seorang badal. ${ }^{31}$ Pengajian al-Qur'an dengan ber-musyafahah kepada kyai atau guru dilakukan para santri tahfidz PMH Pusat dua kali dalam sehari. Musyafahah pertama dilaksanakan untuk menambah hafalan, sedangkan musyafahah kedua dilaksanakan untuk muraja'ah ${ }^{32}$ dan melancarkan hafalan. ${ }^{33}$

\footnotetext{
${ }^{29}$ Mata rantai keilmuan.
}

${ }^{30}$ Sampai.

31 Pengganti kyai. Badal pada umumnya merupakan santri senior yang ditunjuk oleh kyai untuk membantu mentashihkan bacaan al-Qur'an santri tahfidz pemula sebelum ber-musyafahah secara langsung kepada kyai. Pada tahapan persiapan ini, disamping santri tahfidz diharuskan mentashihkan bacaan al-Qur'an kepada badal, ia juga diharuskan menyetorkan hafalan kepada badal sebagai bekal atau tabungan kelak ketika ber-musyafahah kepada kyai.

${ }^{32}$ Mengulang-ulang.

33 Berdasarkan kyai atau guru tempat bermusyafahah al-Qur'an, santri tahfidz PMH Pusat dapat dikelompokkan menjadi beberapa kelompok, yaitu: (1) Santri tahfidz PMH Pusat yang mengaji kepada KH Ahmad Minan Abdillah. Musyafahah dilaksanakan setiap bakda shubuh dan bakda maghrib. Musyafahah bakda shubuh digunakan untuk muraja'ah dan melancarkan hafalan, sedangkan musyafahah bakda maghrib digunakan untuk menambah hafalan. (2) Santri tahfidz PMH Pusat yang mengaji kepada $\mathrm{KH}$ Ahmad Zaky Fuad Abdillah. Musyafahah dilaksanakan setiap bakda 'ashar dan bakda maghrib. Musyafahah bakda 'ashar digunakan untuk muraja'ah dan melancarkan hafalan, sedangkan musyafahah bakda maghrib digunakan untuk menambah hafalan. (3) Santri tahfidz al-Qur'an PMH Pusat yang mengaji kepada KH Abdurrozzaq Najib. Musyafahah dilaksanakan setiap bakda 'ashar dan bakda maghrib.
Di luar setoran hafalan al-Qur'an kepada kyai, santri-santri tahfidz diwajibkan untuk mengikuti beberapa kegiatan khusus santri tahfidz, yaitu: Pertama, mudarasah pagi. Mudarasah merupakan kegiatan mendaras hafalan al-Qur'an yang sudah disetorkan kepada kyai atau badal-nya secara sendirisendiri oleh santri tahfidz. Seluruh santri tahfidz PMH Pusat diwajibkan mengikuti kegiatan mudarasah pagi ini. Kegiatan mudarasah pagi dimulai bakda shubuh sampai pukul 06.00 WIB.

Kedua, mudarasah malam. Seluruh santri tahfidz PMH Pusat diwajibkan mengikuti kegiatan mudarasah malam. Kegiatan mudarasah malam dimulai bakda isya setelah santri-santri tahfidz makan malam sampai pukul 21.00 WIB. Kegiatan ini diselenggarakan di ndalem (rumah) pengasuh pesantren.

Ketiga, ayatan. Ayatan merupakan kegiatan mendaras/membaca al-Qur'an satu ayat satu ayat secara bergantian dalam sebuah kelompok. Seluruh santri tahfidz PMH Pusat diwajibkan mengikuti kegiatan ayatan. Kegiatan ayatan ini dilaksanakan setelah mudarasah malam sampai pukul 21.30 WIB. Kegiatan ini diselenggarakan di ndalem pengasuh pesantren.

Keempat, majlisan dan terminalan. Majlisan merupakan kegiatan membaca al-Qur'an bil-ghaib ${ }^{34}$ dalam satu majlis yang pada umumnya disimak oleh beberapa orang. Sedangkan terminalan merupakan istilah untuk menyebut pos-pos dimana santri tahfidz harus melaksanakan

Musyafahah bakda 'ashar digunakan untuk muraja'ah dan melancarkan hafalan, sedangkan musyafahah bakda maghrib digunakan untuk menambah hafalan. (4) Santri tahfidz al-Qur'an PMH Pusat yang mengaji kepada KH Muhammad Abbad Nafi'. Musyafahah dilaksanakan setiap bakda maghrib saja. Musyafahah bakda maghrib ini digunakan untuk menambah hafalan.

$$
{ }^{34} \text { Dengan hafalan. }
$$


majlisan. Sebagai gambaran, jika terminalan diterapkan pada setiap lipatan pendapatan hafalan 5 juz, maka setiap memperoleh 5 juz, santri tahfidz harus melakukan majlisan dengan cara membaca seluruh pendapatan 5 juz yang didapatkan dalam setiap pos atau terminal secara bil-ghaib dengan disimak oleh santri tahfidz lainnya. Kegiatan majlisan dan terminalan ini diselenggarakan setiap Hari Kamis. Seluruh santri tahfidz PMH Pusat diharuskan untuk mengikuti kegiatan ini. Adapun yang bertugas untuk majlisan dan membaca secara bil-ghaib, maka sesuai dengan jadwal yang telah ditentukan.

Kelima, tartilan. Tartilan merupakan kegiatan membaca al-Qur'an secara pelan-pelan sesuai dengan kaidah ilmu tajwid dan bergiliran yang dilakukan oleh sekelompok santri tahfidz. Kegiatan tartilan ini dilaksanakan setiap Hari Jum'at bakda shubuh sampai selesai. Batasan kegiatan tidak menggunakan waktu, melainkan menggunakan batasan juz al-Qur'an yang dibaca. Biasanya setiap pertemuan membaca 3 juz.

Keenam, imtihan pra semester. Imtihan pra semester dilaksanakan setiap akhir bulan. Santri tahfidz wajib menyetorkan seluruh pendapatan hafalannya selama satu bulan kepada penguji/penyimak dalam imtihan pra semester ini. Jika tidak lulus dalam imtihan pra semester, santri tahfidz tidak diperkenankan menambah setoran hafalan kepada kyai.

Ketujuh, imtihan semester. Imtihan semester dilaksanakan setiap akhir semester (6 bulan sekali). Imtihan semester tahap pertama dilaksanakan pada Bulan Rabi'ul Awwal, sedangkan imtihan semester tahap kedua dilaksanakan pada Bulan Sya'ban. Pada imtihan semester, santri tahfidz harus menyetorkan seluruh pendapatan hafalan selama enam bulan. Jika tidak lulus dalam imtihan semester, disamping tidak diperbolehkan untuk menambah setoran hafalan kepada kyai, santri tahfidz yang tidak lulus semester diwajibkan mengikuti kombongan, yaitu kegiatan karantina yang bertujuan untuk membina hafalan santri tahfidz sampai lulus imtihan semester. Dalam kegiatan kombongan ini, santri dikarantina di ndalem pengasuh pesantren dan tidak diperkanankan pulang sebelum lulus imtihan semester.

\section{Nilai-Nilai Karakter yang Diajarkan di Pesantren}

PMH Pusat sebagai salah satu pesantren tahfidz al-Qur'an tertua di Kajen, selalu mengajarkan, menanamkan dan berusaha mengimplementasikan nilai-nilai karakter yang erat kaitannya dengan tahfidzal-Qur'an. Dari zaman sejak diasuh oleh KH Abdussalam sampai sekarang, nilai-nilai karakter itu masih dilestarikan dan diamalkan. Diantara nilai-nilai karakter terkait tahfidz al-Qur'an yang masih dilestarikan oleh santri-santri tahfidz al-Qur'an PMH Pusat hingga sekarang adalah:

Keikhlasan. Santri tahfidz al-Qur'an PMH Pusat senantiasa diajari tentang arti keikhlasan. Sejak pertama kali masuk PMH Pusat, santri-santri tahfidz diharuskan membaca sebuah surat pernyataan yang salah satu poinnya adalah harus berniat semata-semata karena mencari ridha Allah SWT. Kemudian ketika santri-santri tahfidz menghadap kepada kyai untuk menyatakan bahwa ia ingin mengaji musyafahah alQur'an bil-ghaib, pada umumnya kyai-kyai pengajar al-Qur'an akan menanyakan apakah yang menjadi tujuan utama santri yang ingin menghafalkan al-Qur'an. Jika kyai menemukan bahwa tujuan menghafalkan alQur'an yang diniatkan melenceng, maka kyai akan menegur santri tahfidz agar meluruskan niat semata-mata karena mengharap ridha Allah SWT. Kemudian ketika santri tahfidz sedang menempuh proses menghafalkan alQur'an, kyai sering menasehati para santri 
tahfidz yang pada umumnya sedang tidak menempuh pendidikan formal agar tidak usah memikirkan segala yang belum terjadi, seperti: kalau hanya mengaji al-Qur'an, setelah mondok mau jadi apa? kalau hanya mengaji al-Qur'an, setelah mondok mau kerja apa? dan lain sebagainya. Sebaliknya, kyai akan menasehati para santri agar memasrahkan segala-galanya kepada Allah SWT Yang Maha Mengatur. Kemudian ketika santri tahfidz al-Qur'an sudah khatam dan hendak pulang ke kampung halaman, kyai senantiasa berpesan agar para santrisantri disamping harus menjaga al-Qur'an secara pribadi, mereka juga diharuskan untuk mengamalkan dan mengajarkan alQur'an kepada orang lain. Diantara ajaran kyai yang senantiasa dijadikan pegangan hidup para santri tahfidz al-Qur'an agar selalu memperjuangkan al-Qur'an dengan penuh keikhlasan ketika pulang ke kampung halaman adalah dhawuh ${ }^{35} \mathrm{KH}$ Abdussalam: "Mulanga, nek nganti ora kuat mangan, pathokku okak-okak! "36

Kedisiplinan. Santri-santri PMH Pusat khususnya santri tahfidz al-Qur'an dilatih untuk disiplin dalam mengikuti segala kegiatan yang diselenggarakan oleh pesantren. Kegiatan-kegiatan yang diselenggarakan oleh pesantren pada umumnya menggunakan absensi dan kartu kehadiran. Santri yang tidak mengikuti kegiatan akan mendapatkan takzir atau hukuman. Hal ini dilakukan untuk membentuk karakter kedisiplinan para santri. Dengan peraturan semacam ini, para

${ }^{35}$ Perkataan/nasehat/wasiyat.

36 "Mengajarlah (al-Qur'an)! Kalau sampai tidak kuat makan, batu nisan makamku cabutlah!". Dhawuh KH Abdussalam ini sering sekali didhawuhkan oleh pengasuh-pengasuh PMH Pusat: KH Abdullah Zein Salam dan KH Ahmad Nafi' Abdillah, juga sering didhawuhkan kyai-kyai yang mengajar al-Qur'an di Kajen, seperti: KH Ahmad Zaky Fuad Abdillah, KH Ahmad Minan Abdillah, KH Abdurrozzaq Najib dsb. santri yang belum terbiasa dengan kegiatan yang diselenggarakan oleh pesantren secara bertahap belajar untuk disiplin. Pertamatama, bagi para santri yang belum terbiasa dengan kegiatan-kegiatan pesantren akan terasa berat untuk menjalankan dan bahkan merasa terpaksa untuk melakukan karena khawatir mendapat takzir atau hukuman. Namun setelah terbiasa, hingga terbentuk sebuah pemahaman dan kesadaran tentang arti penting peraturan dan kegiatankegiatan pesantren yang harus dilakukan, para santri tahfidz akan merasa ringan dalam mengemban tugasnya sebagai penghafal alQur'an.

Kesabaran. Ada sebuah pepatah Jawa yang terkenal di kalangan santri tahfidz alQur'an PMH Pusat, yaitu: "sapa sabar, bakal lebar", siapa mampu bersabar, dia akan selesai. Maksudnya adalah siapa saja yang mampu untuk bersabar dalam menghafalkan al-Qur'an, insyaAllah akan kuat untuk mengkhatamkan al-Qur'an secara bil-ghaib, meskipun al-Qur'an terdiri dari ratusan halaman dan ribuan ayat. Sebaliknya, jika seorang santri tahfidz tidak bisa sabar, maka ngaji-nya pun tidak akan selesai-selesai. Hal ini senada dengan salah satu kaidah fiqhiyyah yaitu: man ista'jala syaian qabla awaanih, walam yakun al-mashlahatu, 'uuqiba bihirmanih $^{37}$, yang artinya adalah siapa saja yang tergesa-gesa untuk mendapatkan sesuatu padahal belum waktunya, sementara tidak ada kemaslahatan dalam ketergesa-gesaan itu, maka ia dihukum dengan kegagalan (keterhalangan dalam mendapatkan yang dicita-citakan).

Istiqamah. Salah satu nilai karakter yang selalu diajarkan kepada para santri tahfidz al-Qur'an PMH Pusat adalah sikap istiqamah. Istiqamah berasal dari kata istaqaamayastqiimu yang artinya adalah lurus atau

${ }^{37}$ Jalaluddin As-Suyuthi. tt. Al-Asybah wa AnNadhai.,Surabaya: Al-Hidayah, 
konsisten. $^{38}$ Yang dimaksud dengan istiqamah dalam tahfidz al-Qur'an adalah senantiasa membaca, menjaga hafalan dan berusaha untuk mengamalkan ayatayat yang telah dihafalkan dan disetorkan kepada guru dalam keadaan bagaimanapun juga. Sikap istiqamah dalam tahfidz al-Qur'an ini lah yang menjadi salah satu karakter utama yang seharusnya dimiliki oleh santri tahfidz al-Qur'an. Namun yang dirasakan oleh para santri tahfidz al-Qur'an khususnya santri tahfidz PMH Pusat adalah bahwa sikap istiqamah jauh lebih berat daripada menghafalkan dan melancarkan hafalan alQur'an, karena sifat istiqamah menuntut seseorang untuk melakukan sesuatu secara terus menerus sepanjang hayat. Bagi santrisantri tahfidz, tidak ada kata selesai dalam membaca dan menjaga al-Qur'an, karena al-Qur'an harus senantiasa dibaca, dijaga dan diamalkan selama masih hidup. Dan istiqamah adalah karakter yang benarbenar dibutuhkan para santri tahfidz demi keberlangsungan dan keberlanjutan proses tahfidz al-Qur'an selama hidupnya.

Tawadhu'. Tawadhu' merupakan kata Bahasa Arab yang berasal dari kata kerja tawadla'a-yatawaadla'u, yang artinya adalah merendahkan diri. ${ }^{39}$ Para santri tahfidz percaya bahwa untuk mendapatkan ilmu yang berkah dan bermanfaat salah satu sarat yang harus dipenuhi adalah bersikap tawadlu' kepada siapa saja khususnya kepada guru yang mengajarkan al-Qur'an. Santri itu diibaratkan gelas, sedangkan kyai atau guru adalah seorang yang menuangkan air ke dalam gelas. Air yang dituangkan ke dalam gelas tidak akan penuh jika posisi gelas berada di atas tuangan air, yang merupakan perlambang dari tinggi hati dan sombong. Maka jika ingin air di dalam gelas penuh,

${ }^{38}$ Ahmad Warson Munawwir. 1997. Kamus alMunawwir. Yogyakarta: Pustaka Progressif, h. 1175.

39 Ahmad Warson Munawwir, Kamus alMunawwir..., h 1565. saratnya adalah rendah hati atau tawadlu' dan tidak merasa bisa meskipun yang diajarkan oleh kyai sudah diketahui oleh santri. Santri tahfidz yang mampu menghafalkan al-Qur'an tidak lantas diperbolehkan untuk berbangga diri, karena al-Qur'an bukanlah sesuatu yang patut untuk dibangga-banggakan kepada orang lain. Sejak dulu, pengasuh-pengasuh PMH Pusat mulai masa Kyai Abdussalam, Kyai Abdullah Salam sampai kepada masa Kyai Nafi', melarang santri-santri tahfidz al-Qur'an untuk mengikuti perlombaanperlombaan yang berhubungan dengan tahfidz al-Qur'an seperti musabaqah hifdzil quran (MHQ), musabaqah tilawatil quran (MTQ) dan lain sebagainya.

\section{Falsafah al-Qur'an di Pesantren Mathaliul Huda}

Selain karakter keikhlasan, kedisiplinan, kesabaran, istiqamah dan tawadlu', di PMH Pusat dikenal sebuah falsafah tentang alQur'an yang mencakup karakter-karakter yang harus dimiliki seorang santri tahfidz. Quran itu terdiri dari lima huruf, yaitu qaf, ra', hamzah, alif, dan nun. Kelima huruf ini menyimpan falsafah mendalam dalam bagaimana santri tahfidz berproses.

Huruf pertama adalah qaf. Huruf qaf memiliki sifat qalqalah yang artinya adalah guncang. Maksudnya adalah seorang santri tahfidz al-Qur'an yang memulai untuk mengaji al-Qur'an harus memiliki tekad yang kuat, karena ia akan menghadapi cobaan-cobaan berat yang menghadang dan mengguncangjalannya dalam meraih tujuan. Kesabaran dalam hal ini sangat dibutuhkan, karena siapa yang tidak sabar menghadapi guncangan cobaan dalam menghafal alQur'an, tidak akan selesai dalam menghafal apalagi menjaga al-Qur'an sepanjang hidupnya. Qaf itu tidak bisa dibaca jika tidak diberi harakat atau syakal. Maka diberilah harakat dhommah kepadanya. Makna falsafah dari harakat dhommah dalam huruf 
qaf ini adalah, bahwa seorang santri tahfidz yang diguncang cobaan dan godaan akan mampu melewati segala rintangan tersebut jika dia bersikap seperti dhommah yang artinya adalah kumpul, yakni senantiasa berkumpul dengan orang-orang shaleh dan meminta nasehat serat bimbingannya, dan berkumpul dengan teman-teman yang satu tujuan agar bisa saling menasehati dan saling mengingatkan.

Huruf kedua adalah ra'. Huruf ra' memiliki sifat takrir, yang artinya adalah mengulang-ulang. Makna dari falsafah sifat ra' yang takrir ini adalah bahwa santri tahfidz harus selalu mengulang-ulang bacaan alQur'an yang telah dihafalkannya. Tidak ada kata selesai dalam mengaji al-Qur'an, karena setiap kali mengkhatamkan al-Qur'an, ia harus mengulanginya lagi dari awal. Jika santri tahfidz mampu dan kuat untuk terus menerus mengulang-ulang bacaan al-Qur'an yang telah dihafalkannya, ia akan diberi harakat atau syakal sukun, yang artinya adalah tenang, atau mati. Maksud dari falsafah sukun ra' adalah ketika santri tahfidz mampu senantiasa mengulang-ulang bacaan al-Qur'an, ia akan dianugerahi ketenangan yang luar biasa karena keinginannya kepada selain al-Qur'an telah mati.

Huruf ketiga adalah hamzah. Huruf hamzah memiliki sifat syiddah, yang artinya adalah kuat. Makna dari falsafah hamzah yang bersifat syiddah adalah bahwa santri tahfidz al-Qur'an harus selalu kuat baik dalam menghadapi guncangan-guncangan yang mengganggunya dari mencapai tujuan utama, maupun kuat dalam selalu mengulang-ulang bacaan al-Qur'an yang telah dihafalkannya. Jika santri tahfidz memiliki sifat syiddah, maka ia akan diberi harakat atau syakal fathah, yang artinya adalah terbuka, atau kemenangan. Maksud dari falsafah fathah dalam huruf hamzah adalah, ketika santri tahfidz mampu untuk kuat dalam menghadapi cobaan serta kuat mengulang-ulang bacaan al-Qur'an, maka ia akan dibukakan jalan oleh Tuhan menuju kemenangan.

Huruf keempat adalah alif. Alif merupakan huruf yang tidak bisa berdiri sendiri ketika ingin dibaca, Bentuknya tegak lurus seperti tongkat. Dalam Bahasa Arab, tegak lurus dibahasakan dengan istaqaamayastaqiimu-istiqaamah. Makna falsafah alif yang tegak lurus adalah bahwa seorang santri tahfidz harus bersikap istiqamah dalam menjalankan tahapan pertama yakni sabar dalam menghadapi guncangan, tahapan kedua yakni senantiasa mengulang-ulang bacaan al-Qur'an, dan tahapan ketiga yakni harus selalu kuat. Jika santri tahfidz memiliki sifat alif, ia akan diberi huruf nun.

Huruf kelima adalah nun. Huruf nun memiliki sifat idzlaq, yang artinya adalah licin dan ringan diucapkan. Makna falsafah dari huruf nun yang bersifat idzlaq adalah bahwa ketika santri tahfidz berhasil dalam melewati tahapan-tahapan sebelumnya, ia akan diberikan idzlaq-nya nun, yakni ia akan diberikan keringanan dalam hidup dan matinya, seringan mengucapkan nun. Ia akan mendapatkan syafaat al-Qur'an di dunia dan akhirat. Pada akhirnya, semua yang menjadi keinginannya akan terkumpul, sebagaimana dhommah yang artinya adalah kumpul. ${ }^{40}$

Nilai-nilai karakter religius yang telah disebutkan di atas yang berupa nilai karakter keikhlasan, kedisiplinan, kesabaran, istiqamah, tawadlu' dan falsafah quran, tercermin dan teraktualisasikan dalam sikap-sikap yang harus dimiliki oleh santri tahfidz al-Qur'an PMH Pusat sebagai berikut:

Pertama, mengaji al-Qur'an dengan sungguh-sungguh. Seorang santri yang

\footnotetext{
${ }^{40}$ Falsafah tentang makna huruf-huruf Quran ini diambil dari taushiyah KH Abdurrozzaq Najib di buku album fatwa Pondok Pesantren Mathali'ul Huda - Al-Husna. (Lihat: Pondok Pesantren Mathali'ul Huda Alhusna, Album Fatwa, Kajen, PMH Pusat, 2014)
} 
menghafalkan al-Qur'an harus mempelajari dan menyetorkan hafalan al-Qur'an dengan sungguh-sungguh agar tidak putus di tengah jalan. Karena sebaik-baik pelajar adalah mereka yang mau mempelajari al-Qur'an. Hal ini didasarkan pada sebuah hadits yang diceritakan oleh Sahabat Utsman bin 'Affan RA, bahwa Rasulullah SAW bersabda: "Sebaik-baik kalian adalah dia yang mau belajar al-Qur'an dan mengajarkannya." (HR al-Bukhari). ${ }^{41}$

Kedua, membaca al-Qur'an kapan pun dan dimana pun. Seorang santri yang menghafalkan al-Qur'an harus senantiasa membaca al-Qur'an, agar kelak di hari kiamat mendapatkan syafaat al-Qur'an. Hal ini berdasarkan sebuah hadits yang diceritakan oleh Sahabat Abu Umamah al-Bahily RA, bahwa beliau mendengar Nabi Muhammad SAW bersabda: "Bacalah al-Qur'an, karena ia akan datang sebagai penolong bagi pemiliknya kelak di hari kiamat." (HR Muslim). ${ }^{42}$

Ketiga, mengamalkan isi dan kandungan al-Qur'an. Seorang santriyang menghafalkan al-Qur'an bukan hanya berkewajiban untuk membacanya, melainkan juga harus memahami kandungan al-Qur'an serta mengamalkannya. Hal ini didasarkan pada sebuah ayat al-Qur'an yang terdapat di Surat Fathir, yang artinya: "Sesungguhnya orang-orang yang selalu membaca kitab Allah dan melaksanakan shalat dan menyedekahkan sebagian dari apa yang telah kami berikan secara diam-diam maupun terang-terangan, mereka itu mengharapkan perdagangan yang tidak rugi. "Dalam keterangan lain, dijelaskan bahwa orang yang memahami kitab Allah namun tidak mau mengamalkan diibaratkan seperti seekor keledai yang membawa kitab, berdasarkan firman Allah dalam Surat alJum'ah ayat 5, yang artinya: "Perumpamaan orang-orang yang diberi tugas membawa kitab taurat namun tidak membawanya (mengamalkannya) adalah seperti seekor keledai yang membawa buku-buku tebal..." "44

Keempat, menjaga hafalan yang telah dihafalkan. Seorang santri yang menghafalkan al-Qur'an harus selalu menjaga ayat-ayat al-Qur'an yang telah dihafalkan agar tidak mendapatkan laknat al-Qur'an karena telah melupakan dan lalai dalam menjaganya. Hal ini didasarkan pada firman Allah yang terdapat dalam Surat Thaha yang artinya: "Dan barang siapa berpaling dari peringatanKu, maka sungguh ia akan menjalani kehidupan yang sempit, dan Kami akan mengumpulkannya pada hari kiamat dalam keadaan buta. Dia berkata: Ya Tuhanku, mengapa Engkau kumpulkan aku dalam keadaan buta, padahal dulu aku bisa melihat? Dia (Allah) berfirman: demikianlah, dahulu telah datang kepadamu ayat-ayat Kami, dan kamu mengabaikannya, jadi begitu (pula) pada hari ini kamu diabaikan."

Kelima, mengajarkan al-Qur'an kepada siapa saja yang membutuhkan. Seorang santri yang menghafalkan al-Qur'an harus berkenan mengajarkan al-Qur'an kepada siapa saja yang membutuhkan. Mengajar alQur'an merupakan salah satu upaya dalam menjaga al-Qur'an agar tetap lestari. Dan Rasulullah SAW telah menyatakan bahwa sebaik-baik pengajar adalah dia yang mau menagajarkan al-Qur'an sebagaimana yang dijelaskan dalam sebuah hadits: "Sebaik-baik kalian adalah dia yang mau belajar al-Qur'an dan mengajarkannya." (HR al-Bukhari). ${ }^{46}$

${ }^{44}$ QS al-Jum'ah ayat 5.

${ }^{45}$ QS Thaha ayat 124-126.

46 Yahya an-Nawawy, Riyadh ash-Shalihin, (Surabaya: Al-Hidayah, tt), h. 431. 


\section{Peranan Elemen Pesantren dalam Membentuk Karakter Religius Santri Tahfidz}

Di PMH Pusat, terdapat beberapa elemen yang integral dan masing-masing memiliki peranan penting dalam membentuk karakter religius santri tahfidz al-Qur'an PMH Pusat. Elemen-elemen tersebut meliputi: kyai, pengurus pesantren, teman sejawat, pondok atau asrama, dan mushalla.

\section{Peranan Kyai}

Kyai memiliki beberapa peranan yang signifikan dalam membentuk karakter religius santri tahfidz PMH Pusat. Peranan kyai antara lain adalah: Pertama, sebagai pengasuh, yang mengasuh para santri tahfidz dan mengawal mereka dalam mencapai keberhasilan menghafalkan, mengkhatamkan dan menjaga al-Qur'an. Sebagai pengasuh, kyai merasa bertanggung jawab penuh atas santri-santri yang mengaji kepadanya, karena hubungan serta ikatan antara santri lebih-lebih santri tahfidz alQur'an dengan kyainya bukan hanya di dunia saja melainkan sampai di akhirat sana. Kedua, sebagai pendidik, yang mendidik santri-santri tahfidz baik secara lahiriyah maupun secara dhahir-nya. Di dalam pesantren, dikenal istilah murabbi ar-ruh, yakni pendidik ruh atau jiwa. Sebagai pengasuh pesantren yang merupakan lembaga pendidikan islam tradisional, kyai bukan hanya sekedar mengajarkan ilmu agama, melainkan juga berusaha untuk mendidik para santrinya agar mengamalkan ajaran agama yang telah diajarkan.

Ketiga, sebagai pengajar. Kyai-kyai yang mengajarkan al-Qur'an kepada para santri tahfidz memiliki sebuah prinsip yang selalu dipegang, yaitu bahwa mengajar utamanya mengajar al-Qur'an adalah wajib hukumnya. Maka harus selalu dijalankan, dan tidak boleh ditinggalkan kecuali untuk memenuhi kewajiban yang lainnya.
Keempat, sebagai suri tauladan, yang memberikan contoh laku yang baik secara konkret kepada santri-santrinya. Di pesantren, kyai menjadi tempat rujukan segala permasalahan dan pertimbangan. Apa yang dilakukan kyai adalah sebuah contoh yang senantiasa berusaha untuk ditiru para santri-santrinya.

Kelima, sebagai kontrol sosial. Di dalam sistem pendidikan pesantren, kyai menjadi salah satu kontrol sosial yang paling berpengaruh terhadap keseimbangan sistem sosial lingkungan pesantren sehingga tatanan nilai-nilai yang ada di dalamnya tetap berjalan sebagaimana mestinya.

\section{Peranan Pengurus Pesantren}

Pengurus pesantren merupakan para santri pesantren yang mendapatkan mandat untuk mengatur dan menjalankan peraturan yang ada di pondok pesantren. Diantara beberapa peranan pengurus pesantren dalam membentuk karakter santri tahfidz al-Qur'an adalah sebagai berikut: 1) sebagai pelaksana tatatertib dan peraturan pesantren. Di PMH Pusat, pengurus pesantren merupakan tangan panjang kyai yang mengurus para santri danmenjalankan peraturan-peraturan pesantren dengan baik dan benar. Pengurus pesantren setiap hari berinteraksi dengan santri-santri tahfidz untuk melaksanakan program-program penunjang tahfidz alQur'an yang telah dicanangkan bersamasama. 2) sebagai salah satu elemen kontrol sosial. Pengurus pesantren memiliki peranan mengontrol sistem nilai di pesantren agar tata tertib dan etika di pesantren masih terjaga, sehingga dalam hal ini pesantren secara konsisten mampu menjadi sebuah lingkungan yang berlandaskan pada nilainilai karakter. Lingkungan berbasis nilai karakter inilah yang menurut Lickona menjadi salah satu elemen penting dalam implementasi pendidikan karakter. 


\section{Peranan Teman Sejawat}

Bagi para santri, teman sejawat merupakan saudara, karena sama-sama tinggal di pondok pesantren yang diasuh oleh seorang kyai yang sudah dianggap seperti orang tua sendiri. Keberadaan teman sejawat dalam pembentukan karakter religius santri tahfidz al-Qur'an di PMH Pusat sungguh signifikan. Hal ini diakui sendiri oleh para santri tahfidz al-Qur'an PMH Pusat bahwa keberadaan teman sejawat yang sama-sama sedang menghafalkan al-Qur'an membantu mereka dalam menghafalkan dan menjaga al-Qur'an. Diantara peranan penting teman sejawat dalam pembentukan karakter religius santri tahfidz PMH Pusat adalah: 1) sebagai partner dalam mendaras alQur'an. Di PMH Pusat, di luar pengajian alQur'an bersama kyai, dan di luar kegiatan santri tahfidz yang harus diikuti, para santri tahfidz sering membuat sebuah halaqahhalaqah kecil mudarasah al-Qur'an sendiri dengan teman-teman sejawat mereka. Secara bergiliran, mereka membaca hafalan al-Qur'an, sementara teman sejawatnya menyimak dengan seksama. 2), sebagai partner berlomba-lomba dalam menghafalkan al-Qur'an. Menurut santri-santri tahfidz, teman adalah cermin, dimana mereka bisa melihat dan mengukur dirinya melalui teman-temannya. Di PMH Pusat, terdapat persaingan yang sehat antara satu santri tahfidz dengan santri tahfidz yang lain dalam hal kuantitas dan kualitas bacaan al-Qur'an. Dengan adanya seorang partner bersaing dan berlomba-lomba dalam mencapai hasil terbaik, para santri tahfidz akan memacu dirinya untuk menghasilkan hafalan alQur'an yang terbaik baik dari segi kuantitas maupun dari segi kualitas. 3) sebagai tempat sharing. Peranan yang juga tak kalah penting dari teman sejawat bagi para santri tahfidz al-Qur'an PMH Pusat adalah mereka menjadi tempat sharing dan tempat berdiskusi dalam permasalahan menghafalkan dan menjaga
al-Qur'an. Santri-santri tahfidz al-Qur'an PMH Pusat sering terlihat berdiskusi dengan teman sejawatnya tentang bagaimana cara membaca al-Qur'an yang baik dan benar, bagaimana cara menghafalkan alQur'an yang baik dan benar, bagaimana cara mendaras al-Qur'an yang baik dan benar, bagaimana agar hafalan yang telah dihafalkan tidak lekas hilang dari ingatan, dan lain sebagainya.

\section{Peranan Pondok/Asrama}

Pondok atau asrama yang menjadi tempat tinggal santri sehari-hari ini juga merupakan elemen penting dalam pembentukan karakter religius santri tahfidz al-Qur'an di PMH Pusat. Terdapat beberapa peranan yang dimiliki oleh pondok, yaitu: 1 ), sebagai tempat internalisasi nilai-nilai karakter religius. Pondok atau asrama memiliki peranan menjadi tempat dimana nilainilai karakter diimplementasikan secara langsung dengan tata tertib yang mengikat para santri, sehingga membuat para santri tahfidz yang tinggal di sana mengetahui nilainilai karakter yang tertanam dalam tata tertib tersebut, kemudian menjalankannya secara terus menerus, dan pada akhirnya menjadi karakter yang melekat dalam diri mereka. 2) sebagai tempat mengaktualisasikan karakter religius. Dalam hal ini, pondok memiliki peranan sebagai tempat untuk mengamalkan nilai-nilai karakter yang telah diajarkan kepada para santrinya. PMH Pusat pun demikian, menjadi tempat untuk mengamalkan nilai-nilai karakter utamanya nilai karakter religius santri tahfidz alQur'an. Sebagai contoh, para santri tahfidz biasa melakukan kegiatan-kegiatan rutinan yang berhubungan dengan tahfidz di pondok, seperti: mudarasah, muraja'ah, ayatan, tartilan dan lain sebagainya. 


\section{Peranan Mushalla}

Mushalla memiliki beberapa peranan penting dalam membentuk karakter religius santri tahfidz al-Qur'an PMH Pusat. Selain menjadi tempat untuk berjamaah shalat lima waktu bagi para santri tahfidz, mushalla memiliki peranan lain yang tidak kalah penting, yaitu: Pertama, sebagai tempat mendaras dan mengajarkan alQur'an. Mushalla menjadi tempat yang strategis untuk mendaras al-Qur'an bagi para santri tahfidz. Disamping bisa diniati sambil beri'tikaf, di mushalla para santri tahfidz al-Qur'an PMH Pusat merasa lebih tenang dan fokus dalam menghafalkan dan mendaras ayat-ayat al-Qur'an. Menghafalkan membutuhkan ketenangan dan konsentrasi, sehingga mushalla menjadi salah satu tempat ideal untuk menghafalkan al-Qur'an bagi santri tahfidz al-Qur'an. Kedua, sebagai tempat bermusyawarah. Mushalla menjadi tempat bermusyawarah santri-santri PMH Pusat khususnya santri tahfidz al-Qur'an. Para santri tahfidz PMH Pusat biasa menyelenggarakan musyawarah baik tentang program-program yang terkait dengan kegiatan santri tahfidz, maupun tentang permasalahan serta problemproblem dalam tahfidz al-Qur'an di mushalla PMH Pusat. Secara tidak langsung, mushalla sekaligus menjadi aula bagi santri PMH Pusat, karena PMH Pusat pada saat penelitian ini dilakukan belum memiliki aula.

\section{Peranan Pengajian Al-Qur'an dan Kitab Kuning}

Pengajaran al-Qur'an dan kitab kuning merupakan salah satu ciri khas tradisi pesantren yang sampai sekarang masih dipertahankan di PMH Pusat, karena sebuah prinsip: Mempertahankan tradisi lama yang masih baik dan relevan serta mengakomodir tradisi baru yang lebih baik dan lebih relevan."Adapun peranan pengajian alQur'an dan kitab kuning dalam pembentukan karakter religius santri tahfidz PMH Pusat adalah menjadi pedoman nilai-nilai karakter dan moral. Pengajian al-Qur'an dan kitab kuning dalam tradisi pesantren secara umum maupun dalam tradisi PMH Pusat secara khusus, menjadi media bagi santrisantri tahfidz untuk mengetahui secara mendalam mengenai nilai-nilai karakter dan moral yang harus mereka miliki. Nilai-nilai yang tertanam dalam peraturan-peraturan pesantren pada dasarnya merupakan manifestasi dari nilai-nilai yang terkandung dalam al-Qur'an, al-hadits dan kitab kuning. Khusus untuk karakter santri tahfidz sebagai penjaga al-Qur'an sepanjang hayat, kitab At-Tibyan fi Adab Hamalat al-Qur'an menjadi sumber rujukan yang dikaji di PMH Pusat, dan menjadi pedoman utama tentang bagaimana santri-santri tahfidz PMH Pusat bertutur, bertindak dan bersikap sebagai seorang yang diberi amanah untuk menjaga kalam Ilahi sepanjang hidupnya dengan senantiasa membaca dan mengamalkan ayat-ayatnya.

Pengajian al-Qur'an dan kitab kuning menjadi bagian yang integral dalam sistem pondok pesantren sebagai tempat membentuk karakter religius santri tahfidz al-Qur'an di PMH Pusat. Dari pengajian alQur'an dan kitab kuning, santri-santri tahfidz PMH Pusat mengetahui tentang nilai-nilai kebaikan. Dari kyai pengasuh pesantren dan pengajar al-Qur'an, mereka mendapatkan contoh riil bagaimana nilai-nilai kebaikan itu diamalkan. Dari pondok yang memiliki tatanan masyarakat berbasis nilai, mereka belajar untuk mengamalkan nilai-nilai kebaikan yang diperoleh dari pengajian kitab atau dari pengamatan terhadap perilaku kyai. Dari pengurus pesantren dan teman-teman sejawat, mereka belajar untuk memupuk dan menumbuhkan kesadaran tentang kebaikan, sehingga tiga tahapan pembentukan karakter meliputi pengetahuan, kesadaran dan tindakan yang 
mencerminkan kebaikan dapat terakomodir dalam sistem pendidikan di pondok pesantren.

\section{Model Pembentukan Karakter Religius Santri Tahfidz di PP Mathali'ul Huda}

Secara etimologi, model diartikan sebagai pola (contoh, acuan, ragam, dsb) dari sesuatu yang akan dibuat atau dihasilkan. ${ }^{47}$ Secara terminologi, model dapat dipahami sebagai sebuah kerangka konseptual yang digunakan sebagai pedoman dalam melakukan kegiatan. ${ }^{48}$ Adapun model pembentukan karakter religius santri tahfidz di Pondok Pesantren Mathali'ul Huda Kajen adalah sebagai berikut:

Pertama, pembentukan karakter religius melalui pengajian kitab kuning yang secara khusus membahas tentang etika-etika dalam menghafalkan dan menjaga al-Qur'an. Kitab kuning yang dijadikan pedoman etika tahfidz al-Qur'an ini adalah kitab At-Tibyan fi Adab Hamalat al-Qur'an karya Imam Nawawi, yang dibaca secara rutin oleh $\mathrm{KH}$ Abdurrozzaq setiap Hari Rabu sore. Model pembentukan karakter ini memiliki pola yang sama seperti model pembentukan karakter melalui pembelajaran PPKN di sekolah-sekolah dan pembelajaran Civic Education di pergururan tinggi, sebagaimana yang diungkapkan oleh Doni Koesoema. Dalam kitab At-Tibyan, dijelaskan tentang nilai-nilai karakter yang harus dimiliki dan diamalkan oleh para santri tahfidz al-Qur'an. Dalam hal ini, At-Tibyan menjadi kitab pedoman yang mengajarkan pengetahuan moral (moral knowing) tentang tahfidz al-Qur'an kepada para santri tahfidz. Jika kitab At-Tibyan memberikan pemahaman tentang etika

${ }^{47}$ Departemen Pendidikan Nasional, KBBI..., hlm

48 Syaiful Sagala, 2010. Supervisi Pembelajaran Dalam Profesi Pendidikan: Membantu Mengatasi Kesulitan Guru Memberikan Layanan Belajar Yang Bermutu, Bandung: Alfabeta, h. 62. menjaga dan membaca al-Qur'an, maka alQur'an menjelaskan tentang etika secara keseluruhan.

Kedua, pembentukan karakter religius melalui peraturan yang diwajibkan oleh pesantren. Dapat diibaratkan, pesantren merupakan sebuah negara yang memiliki peraturan serta norma yang harus ditaati oleh para warganya yaitu santrinya. Model pembentukan karakter ini mirip dengan pola model pembentukan karakter melalui peraturan yang diwajibkan oleh negara, yang diungkapkan oleh Doni Koesoema. Peraturan pesantren yang mengikat para santri khususnya santri tahfidz baik mau atau pun tidak mau, suka atau pun tidak suka, tetap harus ditaati dan dijalani oleh para santri. Dalam hal ini, secara bertahap, peraturan pesantren akan merubah kebiasaan para santri tahfidz yang semula tidak memiliki perhatian untuk membaca al-Qur'an menjadi seorang yang mengharuskan dirinya untuk senantiasa membaca dan menjaga alQur'an. Pada mulanya, mungkin peraturan pesantren akan terasa berat bagi para santri baru sehingga mereka akan menaatinya dengan terpaksa. Namun seiring berjalannya waktu, sistem yang ada di pesantren akan membuatnya memiliki kesadaran dari dalam diri untuk menaati peraturan dan menjalankan kewajiban tanpa ada paksaan. Dalam hal ini, peraturan pesantren menjadi tempat untuk membentuk kesadaran moral (moral feeling) dan perilaku moral (moral behavior) para santri tahfidz.

Ketiga, pembentukan karakter religius melalui proses pendidikan yang natural dan informal di pesantren. Pesantren sebagai lembaga pendidikan informal, tempat dimana santri-santri tahfidz berdomisili setiap hari merupakan lingkungan sosial primer bagi mereka, dimana konstruk sosial pesantren sedikit banyak memberikan pengaruhbagi para santri tahfidzyang sedang dan senantiasa berproses untuk mengerti, 
memahami, menyadari, melakukan kebaikan secara terus menerus sepanjang hayat. Di luar sekolah formal maupun pengajian-pengajian kitab kuning atau pun al-Qur'an di pesantren, santri-santri tahfidz berinteraksi dengan masyarakat berbasis moral yang memberinya banyak pelajaran tentang kebaikan, sehingga terbentuklah sistem norma dalam benak dan fikiran santri tahfidz PMH Pusat, sampai kemudian ketika mereka sudah tidak tinggal di pesantren lagi, karakter religius yang mereka miliki itu masih tetap dan tidak luntur karena berbaur dengan masyarakat. Dalam hal ini, para santri tahfidz PMH Pusat akan senantiasa berproses untuk belajar memahami dan mengamalkan karakter yang seharusnya mereka miliki sebagai seorang yang hafidz al-Qur'an selama hidupnya, kendati mereka sudah tidak berada di pondok pesantren.

Adapun proses pembentukan karakter religius santri tahfidz al-Qur'an PMH Pusat melalui beberapa tahapan, yaitu:

Pertama, tahapan pengetahuan tentang karakter religius. Tahapan ini disebut dengan moral knowing. Pengetahuan tentang nilainilai karakter religius yang berhubungan dengan tahfidz al-Qur'an didapatkan santri tahfidz al-Qur'an PMH Pusat melalui beberapa hal, yaitu: (1) Membaca al-Qur'an, (2) Mengikuti pengajian kitab At-Tibyan fi Adab Hamalat al-Qur'an, (3) Membaca peraturan pesantren, (4) Mengamati perilaku kyai sebagai suritauladan, (5) Mengamati perilaku santri tahfidz lain yang juga sedang menghafalkan al-Qur'an.

Kedua, tahapan kesadaran tentang karakter religius. Tahapan ini disebut dengan moral feeling. Setelah santri tahfidz mengetahui nilai-nilai karakter religius yang berkaitan dengan tahfidz al-Qur'an, tahapan selanjutnya adalah menyadari tentang karakter religius. Kesadaran santri tahfidz al-Qur'an PMH Pusat tentang karakter religius dapat tumbuh dengan baik karena beberapa hal, yaitu: (1) Santri tahfidz hidup dalam sebuah konstruk sosial pesantren berikut peraturannya yang mendorong para santri tahfidz untuk senantiasa membaca dan menjaga al-Qur'an, (2) Keberadaan kyai sebagai pengasuh, pendidik dan pengajar al-Qur'an memberikan contoh atau suri tauladan yang baik kepada para santri tahfidz secara langsung, sehingga hal ini dapat menumbuhkan kesadaran dalam diri santri tahfidz untuk meniru perilaku gurunya, (3) Keberadaan pengurus pesantren yang bertugas mengingatkan dan menegur para santri tahfidz al-Qur'an jika mereka lalai dalam menjalankan kewajibannya, (4) Keberadaan teman-teman sejawat yang menjadi partner-partner mudarasah dan musabaqah bil-khairat yang baik, sehingga hal ini memacu semangat para santri tahfidz dalam menghafalkan dan menjaga al-Qur'an.

Ketiga, tahapan pengamalan karakter religius. Tahapan ini disebut dengan moral behavior. Karakter religius dapat diamalkan manakala santri tahfidz telah memiliki pengetahuan, kesadaran dan kemauan untuk melakukan karakter religius itu. Bagi sebagian besar santri tahfidz, mengamalkan karakter religius di PMH Pusat jauh lebih ringan daripada mengamalkannya di rumah. Karena di PMH Pusat, lingkungan benarbenar mendukung. Sedangkan di rumah, belum tentu ditemukan sebuah konstruk lingkungan dan sistem sosial sebagaimana yang ada di pondok pesantren utamanya PMH Pusat. Di PMH Pusat terdapat programprogram yang wajib diikuti oleh semua santri tahfidz al-Qur'an, meliputi: pengajian al-Qur'an bil-ghaib, jam wajib mudarasah pagi, jam wajib mudarasah malam, jam wajib ayatan, jam wajib tartilan, jam wajib majlisan dan terminalan, imtihan pra semester dan imtihan akhir semester. Kegiatan-kegiatan yang hanya ditemukan santri tahfidz PMH Pusat di lingkungan pesantren ini memberikan dampak positif bagi santri- 
santri tahfidz dalam mengamalkan karakter religius yang terkait dengan tahfidz alQur'an.

Keempat, tahapan pembiasaan dalam mengamalkan karakter religius. Mengamalkan sebuah tindakan yang mencerminkan karakter religius saja tidak cukup, karena karakter religius yang berhubungan dengan tahfidz al-Qur'an ini harus senantiasa dibiasakan agar para santri tahfidz terbiasa untuk melakukan, sehingga terbentuklah sistem norma di dalam hati dan fikirannya yang menyatakan bahwa membaca dan menjaga al-Qur'an merupakan suatu keharusan. Pada tahapan pembiasaan dalam mengamalkan karakter religius ini, lingkungan pesantren sangat memberikan pengaruh yang signifikan terhadap para santri tahfidz PMH Pusat. Berdasarkan hasil penelitian yang telah dilakukan peneliti, sebagian besar santri tahfidz yang jarang mengikuti kegiatan-kegiatan yang berkaitan tentang tahfidz al-Qur'an seperti pengajian al-Qur'an bil-ghaib, jam wajib mudarasah pagi, jam wajib mudarasah malam, jam wajib ayatan, jam wajib tartilan, jam wajib majlisan dan terminalan, imtihan pra semester dan imtihan akhir semester tidak memiliki kualitas hafalan yang bagus. Hal ini terbukti ketika diadakan semaan al-Qur'an, santri tahfidz yang jarang mengikuti kegiatan ini tidak bisa melafalkan hafalannya dengan lancar.

Kelima, tahapan penjagaan terhadap karakter religius yang telah dibiasakan dan diamalkan. Bagi para santri tahfidz PMH Pusat, selama masih hidup di dunia tidak ada kata selesai dalam mengemban tugas sebagai seorang hafidz, yakni menjaga alQur'an dengan senantiasa membaca dan mengamalkan ayat-ayatnya. Berdasarkan hasil penelitian yang dilakukan oleh penulis, ada dua usaha yang dilakukan oleh santrisantri tahfidz al-Qur'an yang telah lulus dari pesantren dalam menjaga karakter religius mereka sebagai seorang hafidz, yaitu: (1) Membuat sebuah organisasi mudarasah al-Qur'an bil-ghaib. Organisasi mudarasah al-Qur'an yang dibentuk oleh alumni santri tahfidz PMH Pusat ini bertujuan untuk menjaga nilai-nilai karakter religius anggotanya sebagai seorang hafidz, meliputi: menjaga akhlaq sebagai seorang hafidz, dan juga menjaga kualitas bacaan maupun hafalan anggotanya. (2) Mengajarkan alQur'an kepada masyarakat. Sebagian besar alumni santri tahfidz PMH Pusat yang penulis temui memiliki cara untuk menjaga karakter religius sebagai seorang hafidz dengan mengajarkan al-Qur'an kepada masyarakat sekitar. Mengajarkan al-Qur'an kepada masyarakat sekitar memberikan beberapa dampak yang positif, yaitu: selain santri tahfidz bisa mengamalkan ilmunya kepada orang lain, mereka juga masih bisa menjaga hafalannya dengan menyimak murid-murid yang membaca al-Qur'an kepadanya, dan juga masih bisa menjaga karakter ikhlas dan istiqamah dalam menjaga al-Qur'an, karena sebagaimana yang telah diketahui bahwa guru-guru mengaji al-Qur'an di kampung-kampung pada umumnya tidak mendapatkan bayaran.

\section{PENUTUP}

\section{Kesimpulan}

PMH Pusat sebagai salah satu pesantren yang berbasis pada pembinaan akhlaq para santrinya dapat dijadikan sebagai good model dalam implementasi pendidikan karakter di lembaga pendidikan di Indonesia. PMH Pusat memiliki beberapa elemen integral yang memiliki peranan penting dalam pembentukan karakter religius santri tahfidz. Elemen-elemen tersebut adalah: (1) Kyai yang memiliki peranan sebagai pengasuh, pendidik, pengajar, suri tauladan dan kontrol sosial; (2) Pengurus pesantren yang memiliki peranan sebagai pelaksana 
peraturan atau tata tertib pesantren, serta menjadi salah satu elemen kontrol sosial yang menjaga sistem nilai dan norma di pesantren masih berjalan; (3) Teman sejawat yang memiliki visi dan misi yang sama sebagai santri tahfidz, yang memiliki peranan sebagai partner dalam mendaras al-Qur'an, partner berlomba-lomba dalam menghafalkan al-Qur'an, serta menjadi tempat sharing dalam hal tahfidz al-Qur'an; (4) Pondok atau asrama yang memiliki peranan sebagai tempat internalisasi nilai-nilai karakter religius, sekaligus mengamalkan dan mengaktualisasikannya; (5) Mushalla atau masjid yang memiliki peranan sebagai tempat mendaras dan mengajarkan al-Qur'an, serta sebagai tempat bermusyawarah bagi para santri tahfidz; dan (6) Pengajian al-Qur'an dan kitab kuning sebagai sumber pengetahuan tentang nilainilai karakter.

Nilai-nilai karakter religius yang diajarkan secara langsung kepada santri tahfidz di lingkungan PMH Pusat adalah: (1) Keikhlasan; (2) Kedisiplinan; (3) Kesabaran; (4) Istiqamah; (5) Tawadlu'; dan (6) Falsafah Quran. Keenam nilai karakter religius ini diaktualisasikan dalam sikap-sikap santri tahfidz sebagai berikut: (1) Mengaji al-Qur'an dengan sungguh-sungguh. (2) Membaca al-Qur'an kapan pun dan dimana pun. (3) Mengamalkan isi dan kandungan al-Qur'an. (4) Menjaga hafalan yang telah dihafalkan. (5) Mengajarkan al-Qur'an kepada siapa saja yang membutuhkan.

Model pembentukan karakter religius santri tahfidz al-Qur'an di PMH Pusat melalui: (1) Pembentukan karakter religius melalui pengajian kitab kuning yang secara khusus membahas tentang etika-etika dalam menghafalkan dan menjaga al-Qur'an. (2) Pembentukan karakter religius melalui peraturan yang diwajibkan oleh pesantren.

(3) Pembentukan karakter religius melalui proses pendidikan yang natural dan informal di pesantren. Tahapan-tahapan pembentukan karakter religius santri tahfidz di PMH Pusat adalah sebagai berikut: (1) Tahapan pengetahuan tentang nilai-nilai karakter religius; (2) Tahapan kesadaran tentang karakter religius; (3) Tahapan pengamalan karakter religius; (4) Tahapan pembiasaan karakter religius; (5) Tahapan penjagaan karakter religius sepanjang hayat.

\section{Saran}

Saran peneliti bagi lembaga pendidikan secara umum, tawaran model pembentukan karakter santri tahfidz al-Qur'an di Pondok Pesantren Mathali'ul Huda Pusat Kajen dapat dijadikan acuan di sekolah-sekolah dalam membentuk karakter religius peserta didiknya.

Saran peneliti bagi peneliti-peneliti lain yang mengkaji pesantren, hendaknya merumuskan model-model pendidikan karakter atau pembentukan karakter yang diimplementasikan di pesantren-pesantren di Indonesia, mengingat jumlah pesantren di Indonesia yang begitu banyak dan memiliki corak serta model yang sangat beragam. Dan penelitian ini hanya terfokus pada Pondok Pesantren Mathali'ul Huda Pusat Kajen saja, sehingga belum memberikan gambaran yang komprehensif tentang implementasi pendidikan karakter di seluruh pesantren yang ada di Indonesia.

Saran peneliti bagi Kementrian Agama Republik Indonesia, hendaknya Kemenag melalui badan Litbang-nya melakukan kajian riset secara mendalam tentang implementasi pendidikan karakter di pesantren-pesantren di Indonesia untuk menemukan model serta ragamnya, sehingga dapat dijadikan tawaran dalam implementasi pendidikan karakter baik yang sifatnya nasional maupun yang sifatnya internasional. 


\section{DAFTAR PUSTAKA}

As-Suyuthi, Jalaluddin (tt): Al-Asybah wa An-Nadhair. Surabaya, Al-Hidayah

An-Nawawi, Syarafuddin (tt): at-Tibyan fi Adab Hamalat al-Qur'an. Beirut, Darul Kutub

An-Nawawy, Yahya (tt): Riyadh ash-Shalihin. Surabaya, Al-Hidayah

Departemen Pendidikan Nasional (2008): Kamus Besar Bahasa Indonesia. Jakarta. Gramedia Pustaka Utama

Dhofier, Zamakhsyari (1985): Tradisi Pesantren: Studi Tentang Pandangan Hidup Kiai Dan Visinya Mengenai Masa Depan Indonesia. Jakarta. LP3ES.

Koesoema, Doni A, (2011): Pendidikan Karakter: Strategi Mendidik Anak di Zaman Global. Jakarta: Grasindo.

Koesoema, Doni A (2012): Pendidikan Karakter Utuh dan Menyeluruh. Yogyakarta. Kanisius.

Lickona, Thomas (2013): Educating for Character. Bandung. Nusa Media

Munawwir, Ahmad Warson (1997): Kamus al-Munawwir. Yogyakarta. Pustaka Progressif.

Pondok Pesantren Mathali'ul Huda. Buku Induk Santri dari tahun 1963-sekarang. Pati: PMH Pusat

Pondok Pesantren Mathali'ul Huda Pusat. Anggaran Dasar \& Anggaran Rumah Tangga. Pati: PMH Pusat.

Qomhawi, Muhammad Shodiq (tt): al-Burhan fi Tajwid al-Qur'an. Kairo. Maktabah alAzhar.
Samani, Muhlas \& Haryanto (2013): Pendidikan Karakter: Konsep dan Model. Bandung. Remaja Rosda Karya.

Supardi, Nunus (2007): Sistem Pendidikan Pondok Pesantren, dalam "Peran Pondok Pesantren Dalam Menanamkan Apresiasi Kesenian". Jakarta.

Sagala,Syaiful(2010):SupervisiPembelajaran Dalam Profesi Pendidikan: Membantu Mengatasi Kesulitan Guru Memberikan Layanan Belajar Yang Bermutu. Bandung. Alfabeta.

Hasil wawancara dengan KH Abdurrozzaq Najib pengasuh santri tahfidz PMH Pusat Kajen pada tanggal 1 September 2015.

Hasil wawancara dengan Pengurus Santri Tahfidz PMH Pusat pada tanggal 5 September 2015.

Hasil wawancara dengan santri-santri tahfidz PMH Pusat pada tanggal 6-9 September 2015.

Hasil wawancara dengan Ustadz Muhammad Ridho alumni santri tahfidz PMH Pusat yang menjadi ketua JTQDS (Jam'iyyah Tahfidz al-Qur'an Darus Salam) Jepara pada tanggal 10 September 2015.

Hasil wawancara dengan Ustadz Sujiyanto alumni santri tahfidz PMH Pusat asal Pati pada tanggal 12 September 2015.

Hasil wawancara dengan Ustadz Muhammad Aqib Najib alumni santri tahfidz PMH Pusat asal Rembang pada tanggal 15 September 2015.

http://www.nuonline.com

http://id.wikipedia.org/wiki/Pesantren 